\title{
Benthic communities along a littoral of the Central Adriatic Sea (Italy)
}

\author{
Federica Semprucci · Paola Boi · Anita Manti · \\ Anabella Covazzi Harriague - Marco Rocchi · \\ Paolo Colantoni $\cdot$ Stefano Papa $\cdot$ Maria Balsamo
}

Received: 24 August 2008/Revised: 7 September 2009/Accepted: 10 September 2009/Published online: 22 September 2009

(C) Springer-Verlag and AWI 2009

\begin{abstract}
Bacteria, meio- and macrofauna were investigated at different depths in a coastal area of the Central Adriatic Sea, yielding information about the composition and abundance of the benthic community. In particular, 14 nematode genera were recorded for the first time in the Upper Adriatic Sea. All communities resulted as being significantly different between inshore and offshore stations, especially when the season interaction was considered. Sediment grain size seemed to be the main natural variable, along with trophic resources, affecting the distribution and composition of these benthic components, whilst there was no clear evidence of competition for food sources and predatory pressure between the communities. Meiofauna appeared the most useful community for detecting disturbances and river influences. In particular, the lowest copepod abundance in the shallow waters seemed to be related to a greater anthropogenic disturbance inshore, whilst meiofaunal abundance and diversity together with the nematode maturity index suggest the influence of the Foglia and Metauro rivers and the small stream Arzilla.
\end{abstract}

Communicated by H.-D. Franke.

F. Semprucci $(\bowtie) \cdot$ P. Boi · A. Manti · M. Rocchi .

P. Colantoni · S. Papa · M. Balsamo

Dipartimento di Scienze dell'Uomo, dell'Ambiente e della Natura (Dip.SUAN), Università di Urbino 'Carlo Bo', loc. Crocicchia, 61029 Urbino, Italy

e-mail: federica.semprucci@uniurb.it

\section{A. C. Harriague}

Dipartimento per lo Studio del Territorio e le Sue Risorse

(Dip.Te.Ris), Università di Genova, C.so Europa 26,

16132 Genoa, Italy
Keywords Bacteria $\cdot$ Meiofauna $\cdot$ Macrofauna Adriatic Sea

\section{Introduction}

The three main benthic components, bacteria, meiofauna and macrofauna, represent important ecological indicators (Bilyard 1987; Vincx and Heip 1987; Danovaro 2000), although the meiofauna are the less frequently studied of them. These three components are closely linked by numerous types of interactions and a vast literature concerning them exists, but only the relationships between macrofauna and meiofauna or between meiofauna and bacteria are commonly considered. In particular, the predation pressures of macrofauna upon meiofauna and, reciprocally, of meiofauna upon macrofaunal juveniles are well known (Bell and Coull 1980; Gee 1987) and there is also evidence of a regulatory impact of meiofauna upon bacteria (Montagna 1984; Nilson et al. 1991). Furthermore, previous findings within the literature do not only suggest nutritional interactions or competition, but also the presence of some synergistic relationships (Tenore and Rice 1980; Reise 1985; Tita et al. 2000). It is so evident that the benthic response to changes in environmental conditions (from climate changes to pollution events) can be better understood by taking into account the whole benthic size spectrum (Schwinghamer 1988; Danovaro 2000; Austen and Widdicombe 2006). Nevertheless, to our knowledge, data sets on bacteria, meiofauna and macrofauna have only sporadically been collected in a simultaneous manner in the Mediterranean (Albertelli et al. 1999; Covazzi-Harriague et al. 2006; Papageorgiou et al. 2007) and never in the Adriatic Sea.

The Adriatic Sea, and in particular its northern basin, is a semi-enclosed and a very shallow marine area strongly 
influenced by meteorological conditions and river runoff. During the last decades, eutrophication of the Adriatic Sea has been notably increased due to nutrient enrichment combined with anthropogenic activities. The Po River is evidently the main resource of sediments, nutrients and pollutants influencing the northern Adriatic benthic communities (Moodley et al. 1998; Danovaro et al. 2000), but many smaller Adriatic rivers may also contribute to the delivery of significant amounts of nutrients to the sea of either natural or human origin. The amount of freshwater inputs in the Adriatic Sea generally shows a strong seasonal variability that is related to both the river flow and pattern of sea-water circulation; in turn, the latter is strongly conditioned by thermohaline factors and, to a lesser extent, by winds (Franco et al. 1982; Orlic et al. 1992).

With increases in water depth and distance from the coastline, the impact of the rivers and the effects of hydrodynamism upon the sea bottom notably decrease. As a consequence of the energy reduction, the sediment fine fraction is prevalently deposited offshore. A variation in the texture of the sediments is paralleled by a consequent change in the interstitial volume, organic matter amount, oxygen content, microalgae and bacteria amounts and, not surprisingly, the composition of benthic metazoan communities.

In view of the general scarcity of integrated information on benthic communities in the Adriatic Sea, and given the vulnerability of the coastal system, a survey of the whole benthic size spectrum was carried out along the Marches' coastline (Italy). The study area ran between the mouth of the Foglia river and that of the Metauro river, adjacent to the Natural Regional Park of Monte San Bartolo-a coastline of high naturalistic value. The study area is known to suffer from problems common to other Italian coastal zones, such as progressive coastal erosion, increasing effects arising from tourist infrastructures, and waste and pollutant discharges from rivers. The aims of this study were to elucidate the benthic community spatial distribution pattern and the effects of seasonal variations, and to assess the potential disturbances caused by the rivers upon this benthic community. To do this, sediment samples were taken at six sites at two distinct depths during different seasons in order to test the following hypothesis (1) $\mathrm{H}_{0}$, the communities are not significantly influenced by different depths and by the combination of depths and seasons; (2) $\mathrm{H}_{0}$, the communities are not disturbed by the rivers and show the same temporal responses.

\section{Materials and methods}

Study area and sampling sites

The Adriatic Sea is a long basin in the Central Mediterranean, characterised by an extremely long and morphologically complex coastline, creating a high diversity of hydrodynamic and sedimentary environments. Its shape, together with typical physiographic and climatic features, strongly influences both its hydrodynamic pattern and trophic properties. The hydrology and hydrodynamism, biogeochemical features and ecosystem dynamics of the whole basin have been intensively investigated over the last decades (see Artegiani et al. 1997; Zavatarelli et al. 2000). The general circulation of the Adriatic Sea is cyclonic and mainly determines the distribution of the runoff products introduced by the rivers (Franco et al. 1982). Local currents (longshore and rip currents) mostly arise due to the angle of incidence of the breaking waves and can assume great importance along the coasts regarding sediment transport (driving the northward sediment drift). The transport of coarse sediment by littoral drift along the coasts of the Marches and Emilia Romagna as far as Ravenna has been known about for more than 40 years (Veggiani 1965; Colantoni et al. 1997).

The following six sampling sites were identified along the Marches' coastline between the mouths of the Metauro and Foglia rivers: the mouth of the Foglia river (FO), Pesaro (P), Mont Ardizio (AD), mouth of the Sejore stream (S) and Arzilla stream (AZ) and of the Metauro river (M). At each site, samples were taken from two distinct stations, one at $500 \mathrm{~m}$ from the coastline (station 1 , depth $\cong 5 \mathrm{~m}$ ) and a second at $3,000 \mathrm{~m}$ (station 2 , depth $\cong 12 \mathrm{~m}$ ) (Fig. 1).

Sediment samples were collected from independent deployments of the Van Veen grab (volume 20 1) from the motorboat Sibilla (Regional Environmental Agency for the Marches, ARPAM), and subsampled for the analyses of total organic matter content (TOM), grain size, bacteria, meiofauna and macrofauna. Sampling was performed in

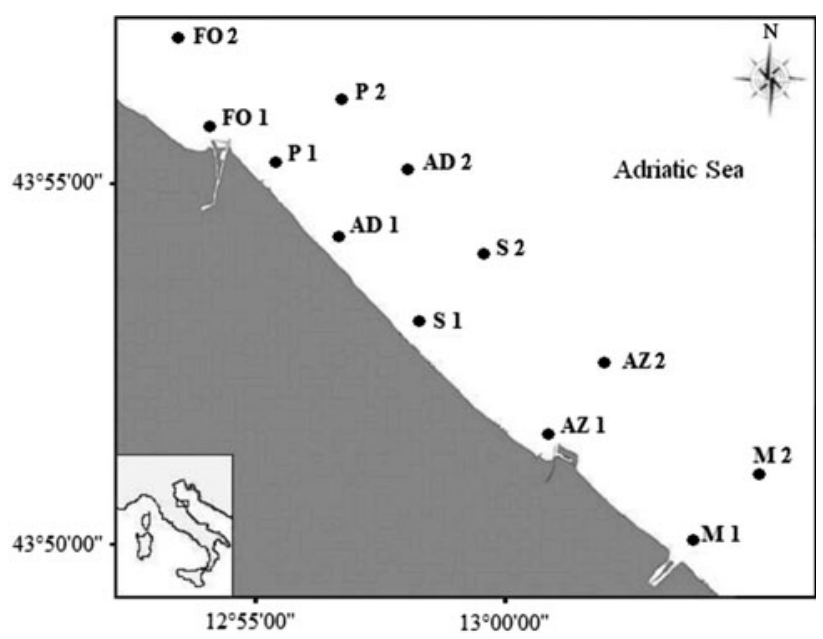

Fig. 1 Location of the sampling sites ( $F O$ Foglia river, $P$ Pesaro, $A D$ Mt. Ardizio, $S$ Sejore torrent, $A Z$ Arzilla torrent, $M$ Metauro river) with coded stations (1 and 2) 
February (winter, W04), June (spring, SP04) and August 2004 (summer, S04), and in March 2005 (winter, W05). Samples for bacterial analyses were collected from spring 2004 onwards in the Metauro and Foglia river mouths exclusively. Three replicates were taken using sterile syringes $(1 \mathrm{ml})$, subsequently fixed with filtered $(0.22 \mu \mathrm{m})$ formaldehyde solution ( $2 \%$ final concentration) and stored at $-20^{\circ} \mathrm{C}$ until analysis. Due to technical problems, not all samples were available for TOM analysis for winter 2004. For the same reason, bacterial counts and multi-parametric probe measures were not available for the FO1 site for spring 2004.

For the study of meiofauna 3 replicate cores (surface area $5.72 \mathrm{~cm}^{2}$ ) were taken down to the depth of $9 \mathrm{~cm}$; the sediment was then treated with $7 \% \mathrm{MgCl}_{2}$ to relax the fauna, and finally fixed with $4 \%$ neutralised formalin in sea-water and stained with Rose Bengal. Macrofauna samples were subsampled using a manual corer (surface area $95 \mathrm{~cm}^{2}$, length $12 \mathrm{~cm}$ ), carefully washed on a $0.5 \mathrm{~mm}$ mesh sieve in order to extract the animals from the sediment, treated with $7 \% \mathrm{MgCl}_{2}$ and then fixed with $10 \%$ neutralised formalin in sea water.

\section{Abiotic parameters}

At each sampling station, depth, temperature, salinity, dissolved oxygen concentration, $\mathrm{pH}$, redox profile (ORP) and chlorophyll- $a$ (Chl- $a$ ) content were measured in the water column using a multi-parametric probe (IDRONAUT). The TOM was gravimetrically determined after loss on ignition (Buchanan and Kain 1971). The sediment samples were first dried at $60^{\circ} \mathrm{C}$ for $6 \mathrm{~h}$ and weighed on a Scaltec SBC21 microbalance (accuracy $0.1 \mathrm{mg}$ ) to obtain the dry weight. The samples were then combusted in a muffle furnace $\left(550^{\circ} \mathrm{C}\right.$ for $\left.4 \mathrm{~h}\right)$ and reweighed to determine the ash fraction. The organic fraction content was calculated by subtracting the ash weight from the total weight.

Grain size analysis was performed by separating the coarse fraction (sand) from the mud fraction (pelite) by washing. The sandy fraction was then analysed by dry sieving, whilst a sedigraph (Sedigraph 5200, Micrometric) was used for the pelite fraction $(<63 \mu \mathrm{m})$. The ' $\phi$ ' notation $\left(-\log _{2}\right.$ size in $\left.\mathrm{mm}\right)$ was used for sediment classification, and the inclusive graphic skewness $\left(\mathrm{Sk}_{\phi}\right)$, graphic mean $\left(\mathrm{Mz}_{\phi}\right)$ and sorting $\left(\sigma_{\phi}\right)$ were calculated using the formulas of Folk and Wards (1957) for statistical analysis.

\section{Bacterial analysis}

To each sample, $20 \mathrm{ml}$ of a freshly prepared solution of filtered $(0.22 \mu \mathrm{m})$ formaldehyde ( $2 \%$ final concentration) diluted in sterilised sea water was added. For the extraction of bacteria, sandy sediments were sonicated three times for
1 min, whilst muddy sediments were processed as follows: TRITON-X (Sigma-Aldrich) was added before sonication and a centrifugation step (10 min, 1,000 rpm) was performed immediately after sonication. Samples were then filtered on Black Nucleopore $(0.22 \mu \mathrm{m})$, treated with a solution constituting five parts of glycerol, one part of Vectashield (Vector Laboratories, D.B.A. Italy S.r.1.), 20\% PBS and $1 \mu \mathrm{g} / \mathrm{ml}$ DAPI. 20 randomly chosen grids from each replicate were then counted using fluorescence microscopy (AHBT3 Vanox, Olympus). All data were normalised to sediment dry weight after desiccation $\left(60^{\circ} \mathrm{C}, 24 \mathrm{~h}\right)$.

Macrofaunal and meiofaunal community study

The macrofaunal organisms retained on the $500 \mu \mathrm{m}$ sieve were sorted, counted and identified to major taxa using a stereomicroscope (Leica G26); only molluscs were identified at the species level.

For the study of meiofauna, sediment samples were sieved through 500-38 $\mu \mathrm{m}$ mesh nets. The residual fraction, retained in a $38 \mu \mathrm{m}$ sieve, was centrifuged three times with Ludox HS 30 colloidal silica (density $1.18 \mathrm{~g} \mathrm{~cm}^{-3}$ ) as described by McIntyre and Warwick (1984) in order to extract the animals, which were counted and sorted per taxon under the stereomicroscope. Nematodes were studied in the Metauro and Foglia sites from the spring 2004 sampling time-point onwards. Around 100 specimens were randomly picked up during the sorting of each meiofaunal replicate (a total of 3,600 specimens), transferred to glycerine and mounted on slides for genus identification under a microscope equipped with Nomarski Differential Interference Contrast optics (Optiphoto-2, Nikon), using the pictorial keys of Platt and Warwick (1983, 1988) and Warwick et al. (1998). Nematodes were also assigned to trophic groups according to Wieser's scheme (1953): selective (1A) and non-selective (1B) deposit feeders; epistrate feeders (2A); predators/omnivores (2B).

Statistical analysis and ecological indices

Analysis of variance (ANOVA) was used to test for significant differences between seasons, sites and stations using the SPSS-12.0 statistical program for Windows. Multiple comparison tests (according to Bonferroni's criterion) were performed to check the significance of the differences between the principal factors at a significance level of $\alpha=0.05$. When data, even after logarithmic transformation $\log (1+x)$, did not meet the assumptions for parametric analysis, Mann-Whitney $U$ or KruskalWallis tests were employed and multiple comparisons were carried out as appropriate. Spearman-rank correlation analysis was also performed to test for significant relationships between the various biological and environmental 
parameters. The computer program PRIMER v.5 was used to perform ANOSIM analyses in order to test for differences between the benthic communities (fourth-root transformed) with respect to both distance along the coast and sea depth across the seasons (2-way crossed ANOSIM, depth $\times$ season and site $\times$ season). Shannon's diversity $\left(H^{\prime}\right)$ and evenness $(J)$ indices for meiofauna and macrofauna were calculated (using $\log _{2}$ for both). Principal component analysis (PCA) was carried out on environmental data in order to visualise the trend of the main abiotic variables. The relative abundances of the benthic components were projected on the factor plane as additional variables without contributing to the results of the analysis. This can provide an insight into the possible influence of the environmental variables upon each benthic group (STATISTICA v.8 computer program).

The maturity index (MI) was calculated for the nematode assemblage (Bongers 1990) as the weighted average of the individual coloniser-persister $(c-p)$ values (Bongers et al. 1991, 1995). This index has been proposed to be a semiquantitative value which gives an indication of the ecosystem conditions on the basis of the composition of the nematode community. All values are reported as mean $\pm \mathrm{SD}$.

\section{Results}

Data on environmental variables are reported in Figs. 2 and 3. The parameters measured by the multi-parametric probe were quite homogeneous across the whole area, and most of them (temperature, salinity, $\mathrm{pH}$ and dissolved oxygen concentration) showed depth-related variations and seasonal fluctuations (Fig. 2). The sediments of the study area were predominantly fine and very fine sands, corresponding to the grain size mode $3-4 \phi(125-63 \mu \mathrm{m})$, whereas the graphic mean $\left(\mathrm{Mz}_{\phi}\right)$ ranged from $2.8 \phi$ at FO1 (S04) to $12 \phi$ at AZ2 (W04). A general increase in the proportions of very fine sands was recorded offshore as well as a reduction in sediment sorting (Fig. 3). The highest values of Chl- $a$ were recorded in spring and summer 2004 with a clear peak in Chl- $a\left(29.8 \mu \mathrm{g}^{-1}\right)$ reached at AZ1 in spring 2004 (Fig. 2). TOM contents ranged between 20.9 at AZ1 and $84.8 \mathrm{mg} \mathrm{g}^{-1}$ at M2. In the whole study area and in all seasons, offshore stations displayed higher TOM contents (on average $50.9 \pm 5.3 \mathrm{mg} \mathrm{g}^{-1}$ ) than inshore stations (on average $25.0 \pm 1.4 \mathrm{mg} \mathrm{g}^{-1}$ ) (Fig. 3).

Bacteria abundances in the Foglia and Metauro ranged from $2.1 \times 10^{8} \pm 3.6 \times 10^{7}$ cell g ${ }^{-1}$ at FO1 (W05) to $1.7 \times 10^{9} \pm 5.3 \times 10^{7}$ cell g $^{-1}$ at FO2 (SP04) (Fig. 4).
Fig. 2 Main environmental parameters measured by multiparametric probe

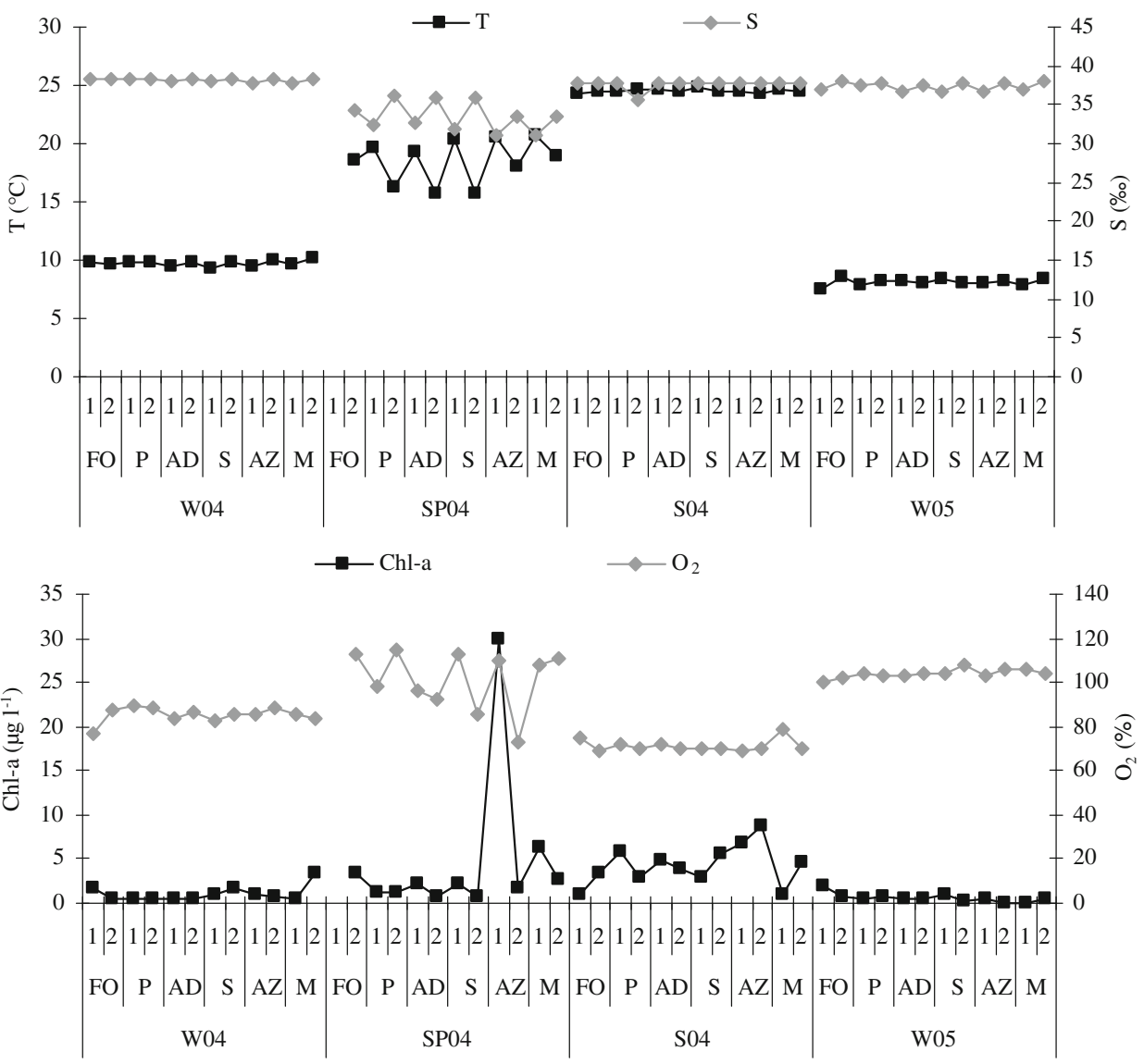


Fig. 3 Sediment parameters: a gravel, sand and mud percentages and $\mathbf{b}$ total organic content (TOM)
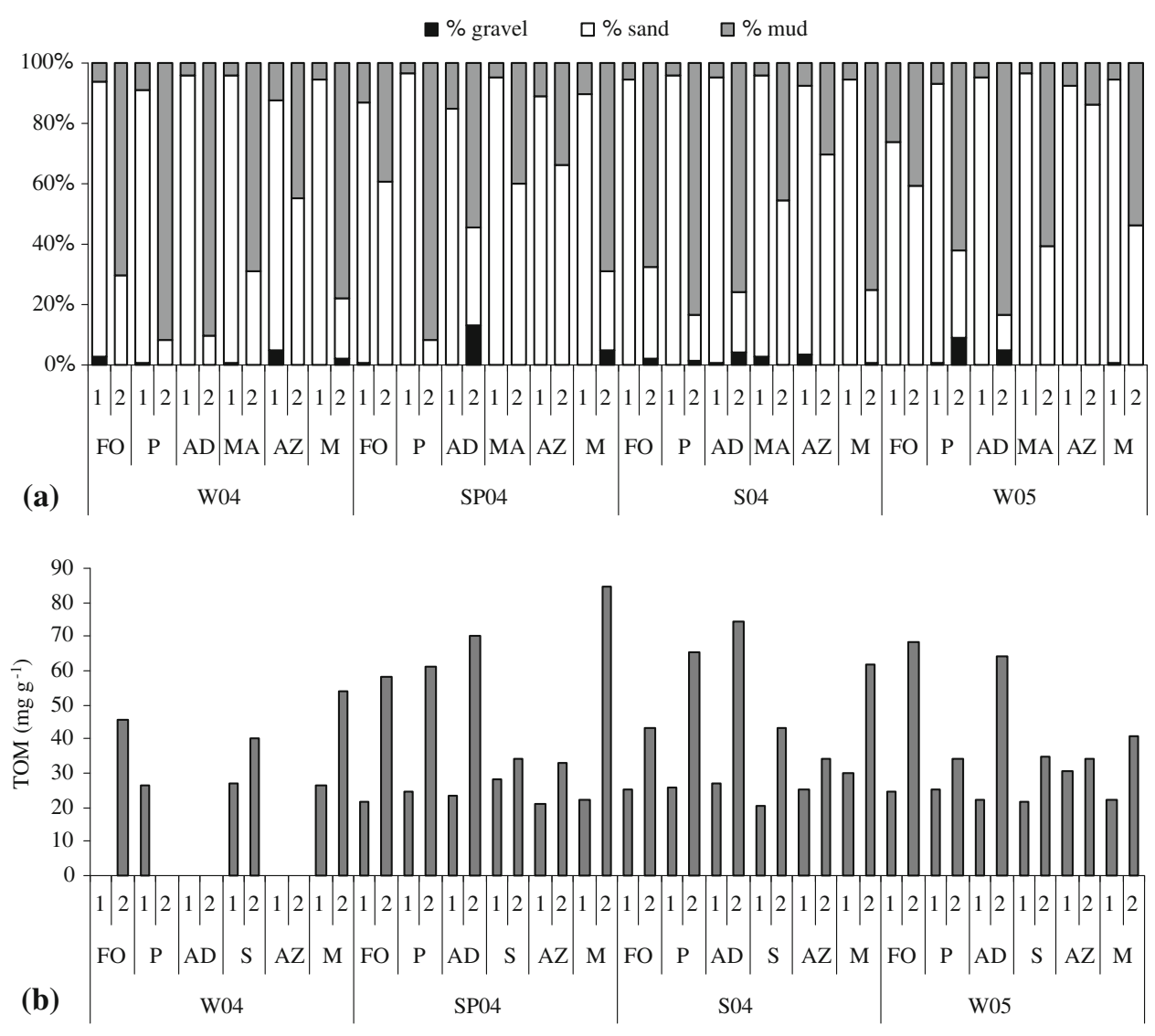

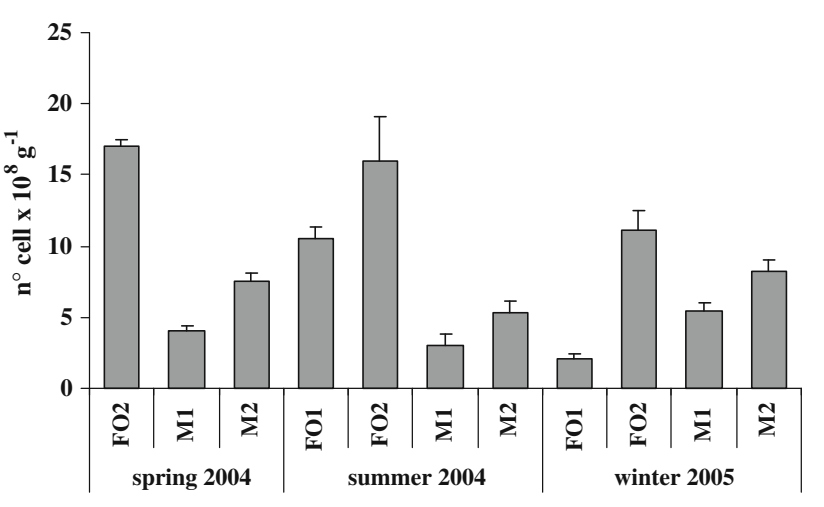

Fig. 4 Bacterial abundance in the sediments of Foglia $(F O)$ and Metauro $(M)$ rivers at different depths (stations 1 and 2)

Abundances were greater offshore than inshore and displayed a correlation with TOM $\left(n=11, r_{\mathrm{s}}=0.51\right.$, $P<0.05)$. Maximum abundances were recorded at the Foglia site but no clear seasonal variations were detected.

Fourteen major meiofaunal taxa were identified: Platyhelminthes, Nemertea, Nematoda, Gastrotricha, Kinorhyncha, Archiannelida, Polychaeta, Oligochaeta, Ostracoda, Copepoda, Cumacea, Anisopoda, Amphipoda and Halacaroidea. Total meiofauna abundances ranged between $117.1 \pm 14.3$ ind. $10 \mathrm{~cm}^{-2}$ (FO1, W04) and $3137.5 \pm 1350.0$ ind. $10 \mathrm{~cm}^{-2} \quad(\mathrm{~S} 2, \quad \mathrm{SP} 04) . \quad$ Overall, nematodes, copepods, turbellarians and polychaetes showed a uniform distribution and the highest abundances, but nematodes were always the numerically dominant group, ranging between 75 and $99 \%$ of the whole community (Fig. 5). Meiofaunal assemblage varied significantly between the stations and seasons (2-way crossed ANOSIM, stations $\times$ seasons, $R=0.31, P=0.001$ and $R=0.46$, $P=0.001$, respectively) with higher mean abundances offshore $\left(823.8 \pm 307.6\right.$ ind. $10 \mathrm{~cm}^{-2}$ inshore and $1352.5 \pm 317.1$ ind. $10 \mathrm{~cm}^{-2}$ offshore). Between the main meiofaunal groups, ANOVA analysis showed the significance of both nematode and copepod abundances in factor interactions (Table 1). Nematode abundances were generally significantly higher at the Sejore and Arzilla sites, followed by the Foglia and Metauro sites. They were usually higher offshore, but exceptions were recorded during the spring when an opposite trend was detected (3-way ANOVA, $P=0.017$, season $\times$ site $\times$ station interaction) (Table 1). Copepod abundances were generally higher at the Pesaro site and lower at the Sejore and Arzilla sites. A general higher copepod abundance was found offshore (3-way ANOVA, $P<0.001$, season $\times$ site $\times$ station interaction). Significant correlations between mean copepod abundances and some sedimentological and trophic parameters were also detected $\left(n=48, \quad \mathrm{Mz}_{\phi} \quad r_{\mathrm{s}}=0.32, \quad P<0.05 ; \quad n=47, \quad\right.$ Chl $-a$ $\left.r_{\mathrm{s}}=0.40, P<0.01\right)$. 
winter 2004

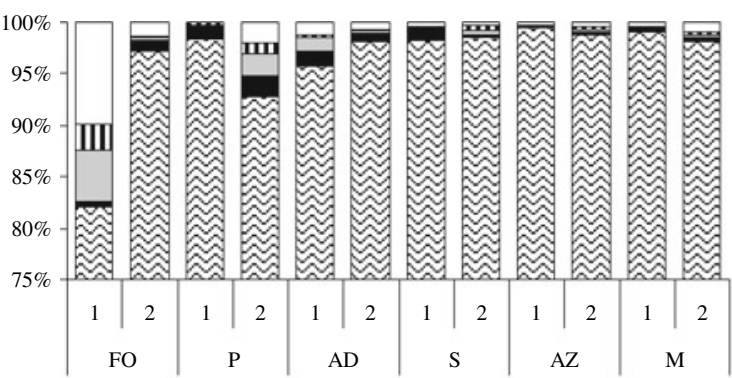

summer 2004

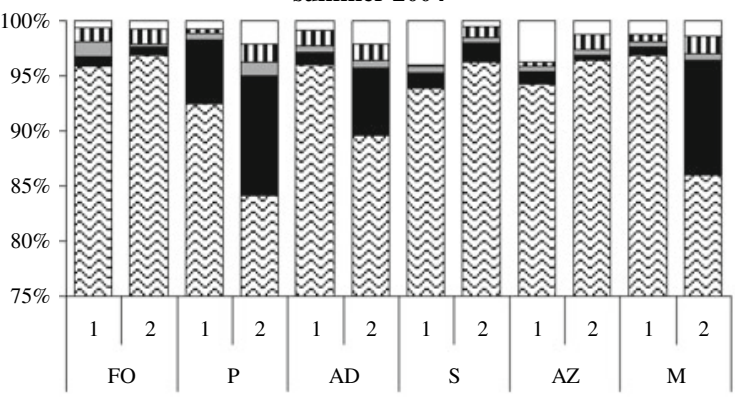

spring 2004
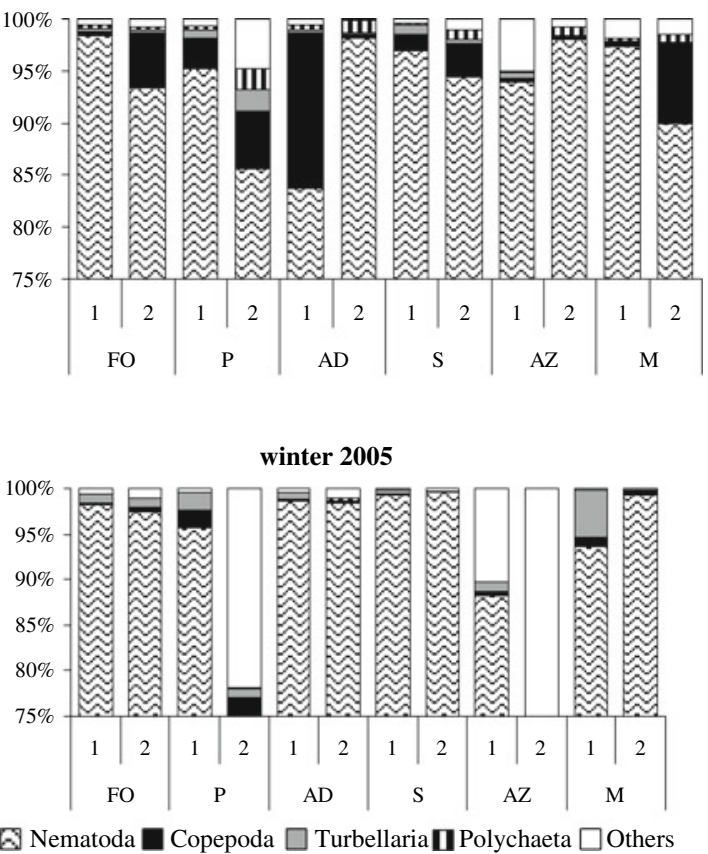

Fig. 5 Seasonal meiofaunal community structure along the coastline between Foglia $(F O)$ and Metauro $(M)$ rivers. The $Y$ axis was cut off at $75 \%$ in order to visualise better the pattern of the other meiofaunal taxa

Table 1 Results of 3-way ANOVA test for nematode and copepod abundances

\begin{tabular}{llllll}
\hline Factors & \multicolumn{2}{l}{ Nematodes } & & \multicolumn{2}{l}{ Copepods } \\
\cline { 2 - 3 } & $F$ & & & $F$ & $P$ \\
\hline Season & 3.27 & 0.024 & & 0.60 & 0.617 \\
Site & 6.42 & 0.000 & & 1.11 & 0.360 \\
Station & 0.02 & 0.893 & & 0.09 & 0.770 \\
Season $\times$ site & 2.47 & 0.004 & & 3.94 & 0.000 \\
Season $\times$ station & 1.30 & 0.279 & & 1.53 & 0.211 \\
Site $\times$ station & 3.02 & 0.014 & & 1.89 & 0.104 \\
Season $\times$ site $\times$ station & 2.73 & 0.017 & & 4.54 & 0.000 \\
\hline
\end{tabular}

$F F$ ratios of mean square, $p$ probability

Meiofaunal diversity $\left(H^{\prime}\right)$ displayed values ranging from 0.07 to 0.98 , and the evenness index $(J)$ from 0.03 to 0.40 (Fig. 6). The Shannon's $\left(H^{\prime}\right)$ and evenness $(J)$ indices were significantly different between the sites (Kruskal-Wallis $H$, $P<0.01$ and 0.001 , for $H^{\prime}$ and $J$ respectively) with the highest values calculated for Pesaro, and the greatest differences (compared to Pesaro) seen for the Sejore, Arzilla and Metauro sites. Significant differences were not detected between inshore and offshore stations (Mann-Whitney $U, P>0.05)$.

A total of 60 nematode genera, belonging to 22 families, were recorded at the Foglia and Metauro sites, with 14 of them being reported for the first time for the Upper Adriatic Sea (Semprucci et al. 2008) (Table 2). Almost half of all the specimens found belonged to either the Comesomatidae (34\%) or Xyalidae (23\%) families, followed by Anticomidae (10\%) and Axonolaimidae (9\%). Four genera occurred with very high abundances: Sabatieria $(31 \%)$, Daptonema (15\%), Anticoma (10\%) and Odontophora (7\%) (Table 2).

In general, the nematode communities found at the Foglia and Metauro sites were similar (ANOSIM, $P>0.05$ ). The highest number of genera were generally found in shallow waters (between 18 and 24) where the most abundant genera were Anticoma (21\%), Sabatieria (14\%), Odontophora (14\%) and Daptonema (9\%). Very clear differences were detected between inshore and offshore stations (ANOSIM, $R=0.98, P=0.002$ ) where the offshore communities were dominated by Sabatieria (49\%), Daptonema (21\%) and Terschellingia (8\%).

The trophic structure of the community (Table 2) was characterised by non-selective (1B) and selective deposit feeders (1A), at 66 and 17\%, respectively; followed by epistrate feeders (2A) at $14 \%$ and predators-omnivores (2B) at only $2 \%$. A more heterogeneous assemblage was observed inshore, where 1B predominated at each station (on average $50 \%$ ); followed by $1 \mathrm{~A}$ at the Metauro site $(26 \%)$ and $2 \mathrm{~A}$ at the Foglia site $(17 \%)$. The offshore community appeared more homogeneous, with a predominance of $1 \mathrm{~B}(81 \%)$ and $1 \mathrm{~A}(13 \%)$.

The diversity index $\left(H^{\prime}\right)$ ranged from 1.05 to 3.36 , and the evenness index $(J)$ from 0.37 to 0.78 (Fig. 6). In contrast with the values recorded for meiofauna taxa, these 

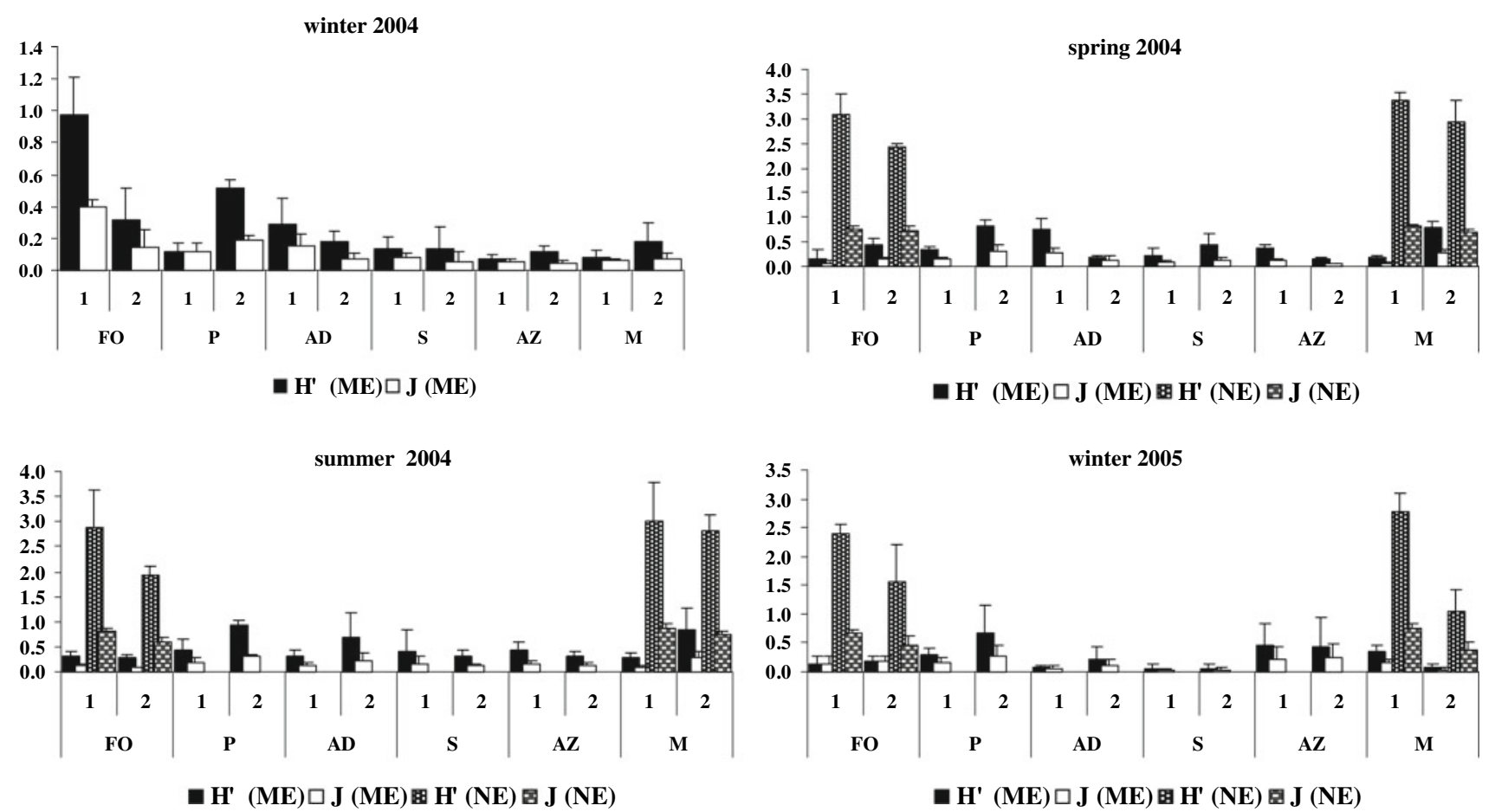

Fig. 6 Shannon's $\left(H^{\prime}\right)$ and Pielou's $(J)$ indices of meiofaunal $(M E)$ and nematode $(N E)$ communities in the study area

indices were in general significantly higher inshore (2-way ANOVA, $P<0.001)$. A significant correlation with graphic mean was only detected for evenness $(n=12$, $\left.r_{\mathrm{s}}=-0.68, P<0.05\right)$. No significant differences were detected between the Foglia and Metauro rivers (2-way ANOVA, $P>0.05$ ).

The maturity index (MI) ranged from 2.05 at M2 (W05) to 2.30 at FO1 (W05), and a noteworthy presence of general opportunistic genera $(c-p=2)$ was observed-up to $82 \%$ of the whole community. MI values were not significantly different between either the inshore and offshore stations or between the two river sites (Mann-Whitney $U$, $P>0.05)$ (Fig. 7).

The abundance of macrofauna ranged between 82307.2 ind. $\mathrm{m}^{-2}$ at AZ1 in summer 2004 and 414.3 ind. $\mathrm{m}^{-2}$ at S2 in winter 2004 (Table 3). No significant differences were observed in macrofaunal abundances between sites or seasons, whereas significant differences were found between inshore and offshore stations (one-way ANOVA, $\quad P<0.05)$ where abundance appeared to decrease with sampling depth. Macrofaunal assemblage only varied significantly in relation to sampling depth and season (2-way crossed ANOSIM, station $\times$ season, $R=0.28, P=0.001$ and $R=0.14, P=0.002$, respectively), and not between the sites (ANOSIM, $P>0.05$ ). In general, molluscs were the most abundant group inshore (66\%), whereas annelids were the most abundant offshore (43\%) (Fig. 8). Nevertheless, a different macrofaunal composition was observed at the Sejore site where a significantly lower abundance of amphipods was detected (Kruskal-Wallis $H, P<0.01$ ). Macrofaunal abundance was significantly correlated with the concentration of Chl- $a$ in the water column $\left(r_{\mathrm{s}}=0.31, P<0.05\right)$, the mean grain size and the sorting coefficient $\left(n=48, r_{\mathrm{s}}=-0.30\right.$, $P<0.05$ for both parameters).

A total of 50 mollusc species belonging to 25 different families were recorded in the area. Semelidae $(40 \%)$, Corbulidae (25\%) and Donacidae (13\%) showed the highest abundances. Overall, the most abundant species of molluscs were Chamelea gallina (37\%), Lentidium mediterraneum (21\%), Donax semistriatus (13\%) and Cultrensis adriaticus (6\%). In general, mollusc diversity and evenness was low, on average $1.8 \pm 0.6$ and $0.6 \pm 0.2$, respectively. The Shannon index $\left(H^{\prime}\right)$ ranged from 0.00 to 3.00 and Pielou values $(J)$ from 0.00 to 0.89 (Table 3 ). There were no significant differences between sites (2-way ANOVA, $P>0.05$ ) or between sampling depths (2-way ANOVA, $P>0.05$ ) for either of these indices.

PCA was used to visualise the trends of the bacteria, meiofauna and macrofauna communities in relation to the main environmental variables for the Foglia and Metaruro sites (Fig. 9). Two principal components were identified that together explained $65 \%$ of the data variance. Depth (PC1), explained $41 \%$ of the variance and was primarily affected by the sediment variables, sand, mud and TOM, followed by gravel and Chl- $a$. Season (PC2) explained $24 \%$ of the variance and was mainly affected by oxygen and salinity followed by temperature and Chl- $a$. Bacteria 
Table 2 Genera abundance (\%) and trophic groups of nematode community at Foglia (FO) and Metauro (M) rivers

\begin{tabular}{|c|c|c|c|}
\hline Family & Genus & Trophic group & $\%$ \\
\hline Anoplostomatidae & Chaetonema & $1 \mathrm{~B}$ & 1.2 \\
\hline Anticomidae & Anticoma & $1 \mathrm{~A}$ & 10.5 \\
\hline Enchelidiidae & Bathyeurystomina & $2 \mathrm{~B}$ & $<0.1$ \\
\hline \multirow[t]{2}{*}{ Oncholaimidae } & Adoncholaimus & $2 \mathrm{~B}$ & $<0.1$ \\
\hline & Oncholaimellus & $2 \mathrm{~B}$ & 0.1 \\
\hline \multirow[t]{2}{*}{ Oxystominidae } & Halalaimus & $1 \mathrm{~A}$ & $<0.1$ \\
\hline & Thalassoalaimus & $1 \mathrm{~A}$ & 1.0 \\
\hline Thoracostomopsidae & Mesacanthion & $2 \mathrm{~B}$ & 1.0 \\
\hline Trefusiidae & Cytolaimium & $2 \mathrm{~A}$ & 0.1 \\
\hline Aegialoalaimidae & Aegialoalaimus & $1 \mathrm{~A}$ & 0.1 \\
\hline \multirow[t]{2}{*}{ Ceramonematidae } & Ceramonema & $1 \mathrm{~A}$ & $<0.1$ \\
\hline & Pselionema & $1 \mathrm{~A}$ & 0.1 \\
\hline \multirow[t]{6}{*}{ Chromadoridae } & Chromadora & $2 \mathrm{~A}$ & 1.5 \\
\hline & Chromadorella & $2 \mathrm{~A}$ & $<0.1$ \\
\hline & Chromadorina & $2 \mathrm{~A}$ & $<0.1$ \\
\hline & Chromadorita & $2 \mathrm{~A}$ & 0.2 \\
\hline & Dichromadora & $2 \mathrm{~A}$ & 1.3 \\
\hline & Prochromadorella & $2 \mathrm{~A}$ & 1.7 \\
\hline \multirow[t]{3}{*}{ Comesomatidae } & Dorylaimopsis & $1 \mathrm{~A}$ & 0.1 \\
\hline & Sabatieria & $1 \mathrm{~B}$ & 31.3 \\
\hline & Setosabatieria & $1 \mathrm{~B}$ & 2.7 \\
\hline \multirow[t]{4}{*}{ Cyatholaimidae } & Longicyatholaimus & $2 \mathrm{~A}$ & $<0.1$ \\
\hline & Nannolaimoides & $2 \mathrm{~A}$ & 3.3 \\
\hline & Paralongicyatholaimus & $2 \mathrm{~A}$ & 0.3 \\
\hline & Pomponema & $2 \mathrm{~A}$ & 0.5 \\
\hline \multirow[t]{2}{*}{ Desmodoridae } & Desmodora & $2 \mathrm{~A}$ & 0.1 \\
\hline & Molgolaimus & $2 \mathrm{~A}$ & $<0.1$ \\
\hline \multirow[t]{3}{*}{ Ethmolaimidae } & Comesa & $1 \mathrm{~B}$ & $<0.1$ \\
\hline & Filitonchus & $1 \mathrm{~A}$ & 0.2 \\
\hline & Neotonchus & $2 \mathrm{~A}$ & 1.5 \\
\hline \multirow[t]{2}{*}{ Leptolaimidae } & Halaphanolaimus & $1 \mathrm{~A}$ & $<0.1$ \\
\hline & Leptolaimus & $1 \mathrm{~A}$ & 0.9 \\
\hline \multirow[t]{3}{*}{ Selachnematodae } & Gammanema & $2 \mathrm{~B}$ & $<0.1$ \\
\hline & Halichoanolaimus & $2 \mathrm{~B}$ & $<0.1$ \\
\hline & Synonchiella & $2 \mathrm{~B}$ & 0.1 \\
\hline \multirow[t]{5}{*}{ Axonolaimidae } & Axonolaimus & $1 \mathrm{~B}$ & $<0.1$ \\
\hline & Odontophora & $1 \mathrm{~B}$ & 7.0 \\
\hline & Odontophoroides & $1 \mathrm{~B}$ & $<0.1$ \\
\hline & Paradontophora & $1 \mathrm{~B}$ & 2.3 \\
\hline & Synodontium & $1 \mathrm{~B}$ & $<0.1$ \\
\hline \multirow[t]{2}{*}{ Diplopeltidae } & Campylaimus & $1 \mathrm{~B}$ & $<0.1$ \\
\hline & Southerniella & $1 \mathrm{~A}$ & 0.3 \\
\hline \multirow[t]{5}{*}{ Linhomoidae } & Eumorpholaimus & $1 \mathrm{~B}$ & $<0.1$ \\
\hline & Linhomoeus & $2 \mathrm{~A}$ & 0.3 \\
\hline & Metalinhomoeus & $1 \mathrm{~B}$ & 0.9 \\
\hline & Paralinhomoeus & $1 \mathrm{~A}$ & $<0.1$ \\
\hline & Terschellingia & $1 \mathrm{~A}$ & 4.0 \\
\hline
\end{tabular}

Table 2 continued

\begin{tabular}{lllr}
\hline Family & Genus & Trophic group & $\%$ \\
\hline Monhysteridae & Monhystera & 1B & $<0.1$ \\
Sphaerolaimidae & Doliolaimus & 2B & $<0.1$ \\
& Sphaerolaimus & 2B & 0.7 \\
& Subsphaerolaimus & 2B & $<0.1$ \\
Xyalidae & Cobbia & 2A & 3.2 \\
& Daptonema & 1B & 14.8 \\
& Linhystera & 1B & 0.1 \\
& Paramonhystera & IB & 0.1 \\
& Scaptrella & 1B & $<0.1$ \\
& Stylotheristus & 1B & 2.6 \\
& Theristus & 1B & 0.5 \\
& Tricotheristus & 1B & 2.0 \\
& Valvaelaimus & 2A & $<0.1$ \\
\hline
\end{tabular}

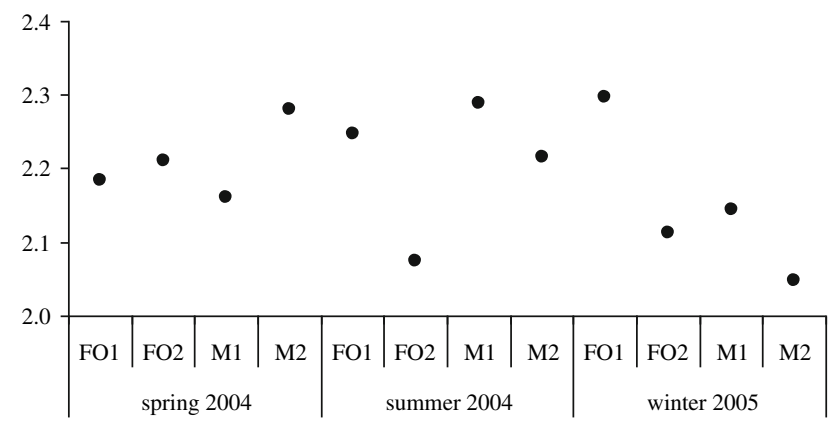

Fig. 7 Maturity Index calculated in the nematode assemblage at Foglia $(F O)$ and Metauro $(M)$ rivers

and meiofauna appeared to follow increases in TOM content and amount of mud especially, whilst macrofauna followed increases in the amount of sand. When the most abundant nematode genera were projected on the factor plane as supplementary variables, a more heterogeneous genera composition was detected inshore (Fig. 10). Sabatieria and Daptonema were both found inshore and offshore, but their abundances were much higher offshore. PCA analysis carried out on the whole area revealed an influence of depth (PC1, explaining 38\%) upon the mollusc community: C. gallina, L. mediterraneum, D. semistriatus and $C$. adriaticus were more abundant inshore, in sandy sediments, whereas Corbula gibba, Scapharca demiri and Abra prismatica were the dominant species in the offshore stations (Fig. 11). Season (PC2, explaining 23\%) showed temporal fluctuations of the main species. In particular, increases in temperature and Chl- $a$ were correlated with increases in L. mediterraneum (Fig. 11). When the whole area was considered for PCA analysis, the same influencing factors and variables were identified, although Chl- $a$ values 
Table 3 Macrofaunal total density (ind. $\mathrm{m}^{-2}$ ) and mollusc diversity and evenness indices

\begin{tabular}{|c|c|c|c|c|c|}
\hline Season & Site & Station & $\begin{array}{l}\text { Total } \\
\text { density }\end{array}$ & $\begin{array}{l}\text { Mollusc } \\
\text { diversity }\end{array}$ & $\begin{array}{l}\text { Mollusc } \\
\text { evenness }\end{array}$ \\
\hline \multirow[t]{12}{*}{ Winter 2004} & \multirow[t]{2}{*}{$\mathrm{FO}$} & 1 & $17,751.4$ & 1.0 & 0.4 \\
\hline & & 2 & $9,052.5$ & 3.0 & 0.8 \\
\hline & \multirow[t]{2}{*}{$\mathrm{P}$} & 1 & $1,597.5$ & 1.5 & 0.7 \\
\hline & & 2 & $7,158.6$ & 1.2 & 0.5 \\
\hline & \multirow[t]{2}{*}{$\mathrm{AD}$} & 1 & $4,791.8$ & 1.8 & 0.7 \\
\hline & & 2 & $6,745.2$ & 1.1 & 0.4 \\
\hline & \multirow[t]{2}{*}{$\mathrm{S}$} & 1 & $4,023.7$ & 1.5 & 0.6 \\
\hline & & 2 & 414.3 & 1.2 & 0.7 \\
\hline & \multirow[t]{2}{*}{$\mathrm{AZ}$} & 1 & $14,697.3$ & 2.0 & 0.6 \\
\hline & & 2 & $11,360.9$ & 1.7 & 0.7 \\
\hline & \multirow[t]{2}{*}{ M } & 1 & $13,371.8$ & 2.5 & 0.6 \\
\hline & & 2 & $5,679.0$ & 1.9 & 0.6 \\
\hline \multirow[t]{12}{*}{ Spring 2004} & \multirow[t]{2}{*}{$\mathrm{FO}$} & 1 & $8,815.3$ & 1.6 & 0.5 \\
\hline & & 2 & $27,809.6$ & 1.9 & 0.5 \\
\hline & \multirow[t]{2}{*}{$\mathrm{P}$} & 1 & $6,211.9$ & 1.9 & 0.7 \\
\hline & & 2 & $6,945.0$ & 2.2 & 0.7 \\
\hline & \multirow[t]{2}{*}{$\mathrm{AD}$} & 1 & $7,632.5$ & 2.5 & 0.9 \\
\hline & & 2 & $19,110.7$ & 1.2 & 0.4 \\
\hline & \multirow[t]{2}{*}{$\mathrm{S}$} & 1 & $4,733.6$ & 1.7 & 0.7 \\
\hline & & 2 & $1,242.0$ & 0.6 & 0.4 \\
\hline & \multirow[t]{2}{*}{$\mathrm{AZ}$} & 1 & $32,306.6$ & 1.1 & 0.4 \\
\hline & & 2 & $13,845.5$ & 1.6 & 0.5 \\
\hline & \multirow[t]{2}{*}{ M } & 1 & $21,715.2$ & 2.4 & 0.8 \\
\hline & & 2 & $7,336.0$ & 2.2 & 0.7 \\
\hline \multirow[t]{12}{*}{ Summer 2004} & \multirow[t]{2}{*}{$\mathrm{FO}$} & 1 & $9,703.3$ & 1.0 & 0.3 \\
\hline & & 2 & $3,431.7$ & 2.6 & 0.7 \\
\hline & \multirow[t]{2}{*}{$\mathrm{P}$} & 1 & $16,685.0$ & 1.7 & 0.7 \\
\hline & & 2 & $10,176.3$ & 1.6 & 0.5 \\
\hline & \multirow[t]{2}{*}{$\mathrm{AD}$} & 1 & $17,454.8$ & 1.7 & 0.6 \\
\hline & & 2 & $8,342.8$ & 2.2 & 0.7 \\
\hline & \multirow[t]{2}{*}{$\mathrm{S}$} & 1 & $14,082.8$ & 1.9 & 0.6 \\
\hline & & 2 & $11,715.7$ & 2.0 & 0.5 \\
\hline & \multirow[t]{2}{*}{$\mathrm{AZ}$} & 1 & $82,307.2$ & 1.5 & 0.4 \\
\hline & & 2 & $1,893.0$ & 1.5 & 0.8 \\
\hline & \multirow[t]{2}{*}{ M } & 1 & $21,005.7$ & 2.0 & 0.6 \\
\hline & & 2 & $5,443.2$ & 1.7 & 0.5 \\
\hline \multirow[t]{12}{*}{ Winter 2005} & $\mathrm{FO}$ & 1 & $5,502.7$ & 1.4 & 0.5 \\
\hline & & 2 & $7,278.1$ & 2.3 & 0.8 \\
\hline & $\mathrm{P}$ & 1 & $9,467.4$ & 2.9 & 0.8 \\
\hline & & 2 & $17,928.4$ & 2.5 & 0.7 \\
\hline & $\mathrm{AD}$ & 1 & $17,692.1$ & 2.3 & 0.6 \\
\hline & & 2 & $5,502.9$ & 3.0 & 0.8 \\
\hline & $\mathrm{S}$ & 1 & $12,071.0$ & 1.6 & 0.6 \\
\hline & & 2 & 828.4 & 0.0 & 0.0 \\
\hline & $\mathrm{AZ}$ & 1 & $34,082.7$ & 2.4 & 0.6 \\
\hline & & 2 & $10,118.3$ & 1.8 & 0.5 \\
\hline & M & 1 & $37,218.9$ & 1.8 & 0.6 \\
\hline & & 2 & $5,561.9$ & 2.4 & 0.7 \\
\hline
\end{tabular}

were found to be higher inshore and mainly due to the Arzilla stream.

An additional PCA was performed using the total abundance of the three communities as active variables in order to visualise the potential interactions between them (PC1 and PC2 together explained 90\% of the variance) (Fig. 12). It showed a similar trend for bacteria and meiofauna, whilst a greater increase was detected for macrofauna especially at Station 1 of the Metauro site.

\section{Discussion}

Distribution and ecology of benthic communities in relation to depth and season

All three of the benthic communities studied appeared to be influenced by depth; of the environmental parameters examined, TOM, sediment fractions and Chl- $a$ appeared to be the main parameters contributing towards the differences between the two depths studied (Fig. 9). The bacterial abundances seemed to be primarily influenced by food supply and in particular by TOM content that was greater offshore where the highest bacterial abundances were found. A strong relation between TOM and depth was also reported in a previous study carried out along the nearby coastline of Monte San Bartolo (Covazzi-Harriague and Bittoni 2003). These findings were in accordance with the frequently observed greater retention of sediment-bound organic matter and microorganisms in the finest sediments (Herndl et al. 1989; Van Duyl and Kop 1994; Albertelli et al. 1999; Covazzi Harriague et al. 2006). Both the structure and abundance of meiofaunal and macrofaunal communities resulted as being significantly different between inshore and offshore stations, especially when the interaction of season was considered. This difference was most likely due to seasonal variations in water masses that can differentially affect the communities at different depths, but it may also have been brought about by variations in riverine inputs that for certain taxa could represent variations in food availability (see Chl- $a$ ) or reflect an anthropogenic disturbance (see below). As demonstrated by PCA, from the environmental variables, Chl- $a$ was the parameter that contributed both to depth and seasonal differences (Fig. 9). Chl- $a$ is an indicator of a fresh and high quality trophic source, the sedimentation of which can enrich the sea bottom so becoming an important resource also for benthic communities (Boon and Duineveld 1998). Within the study area, Chl- $a$ showed a first peak during spring 2004, linked to the massive input of nutrients from the rivers (see Arzilla stream), and a second peak during the summer of the same year; probably related to the natural increase in phytoplankton activity (Fig. 2). The abundance of copepods was highly correlated to this trophic parameter; their levels increased during the phytoplankton blooms as do the level of recruits of the species L. mediterraneum. The coupling of this autotrophic 


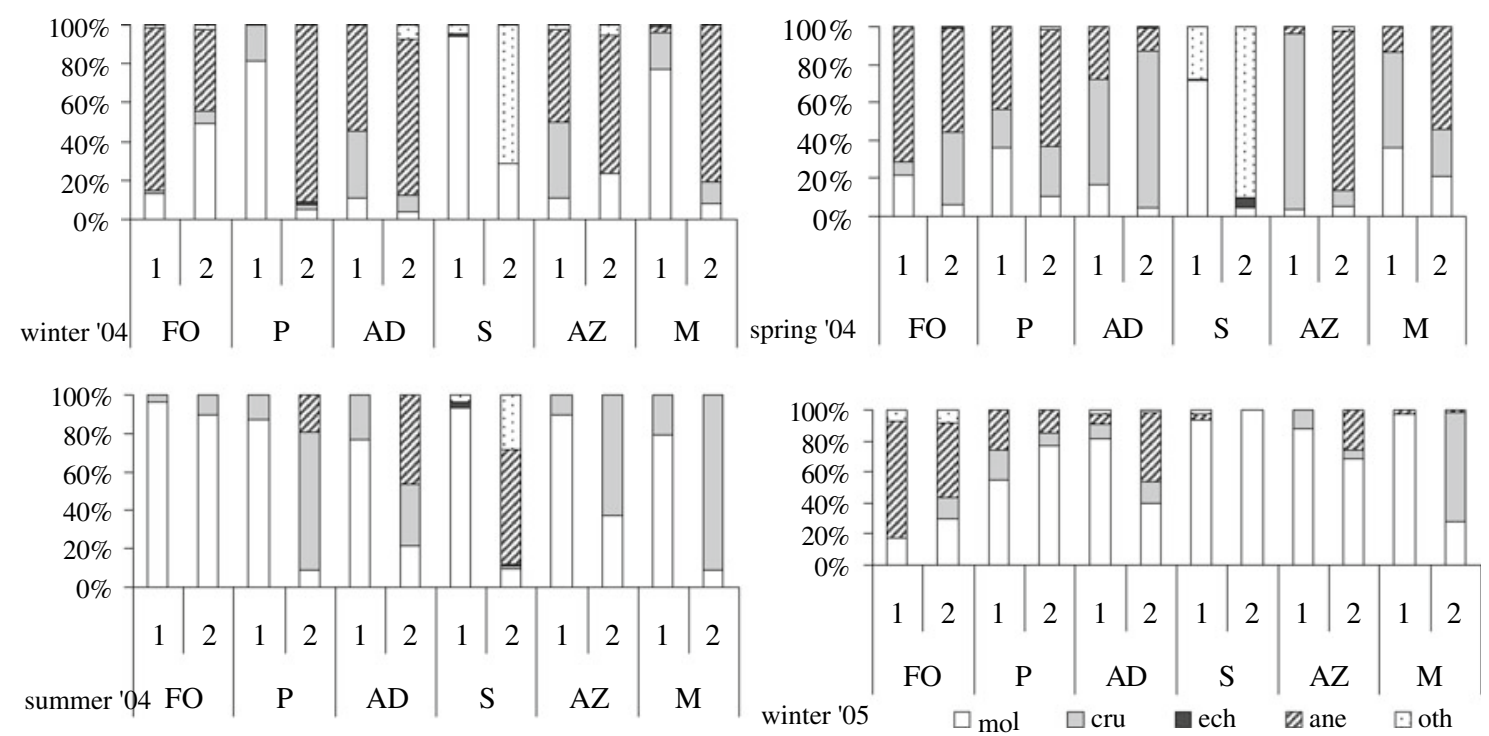

Fig. 8 Seasonal macrofaunal community structure along the coast between the Foglia $(F O)$ and Metauro $(M)$ rivers $(m o l$ molluscs, cru crustaceans, ech echinoderms, ane annelids, oth others)

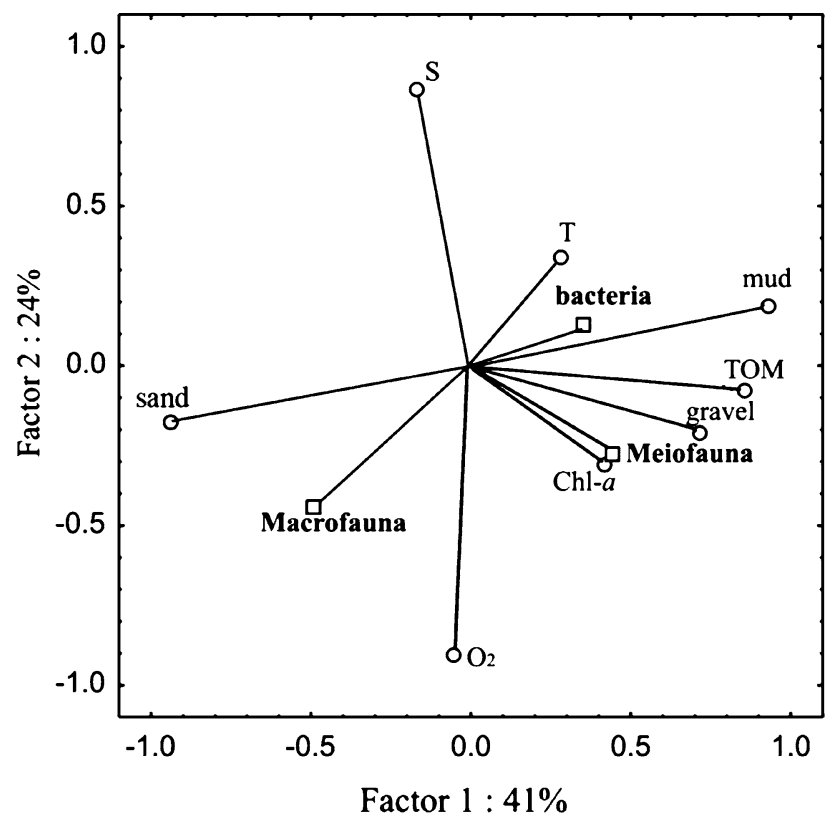

Fig. 9 PCA analysis carried out on the main environmental variables of the Foglia and Metaruro rivers. The relative abundances of bacteria, meiofauna and macrofauna were projected on the factor plane as supplementary variables without contributing to the results of the analysis

component with the recruitment of suspension feeders has also been reported for other coastal areas (Møhlenberg and Kiørboe 1981; Covazzi Harriague et al. 2007).

The meiofaunal community was prevalently made up of deposit feeders and their increase offshore, mainly due to the nematodes, seemed to follow the increases in the sediment fine fraction and food supply (TOM and bacteria). To the contrary, the abundance of macrofauna decreased

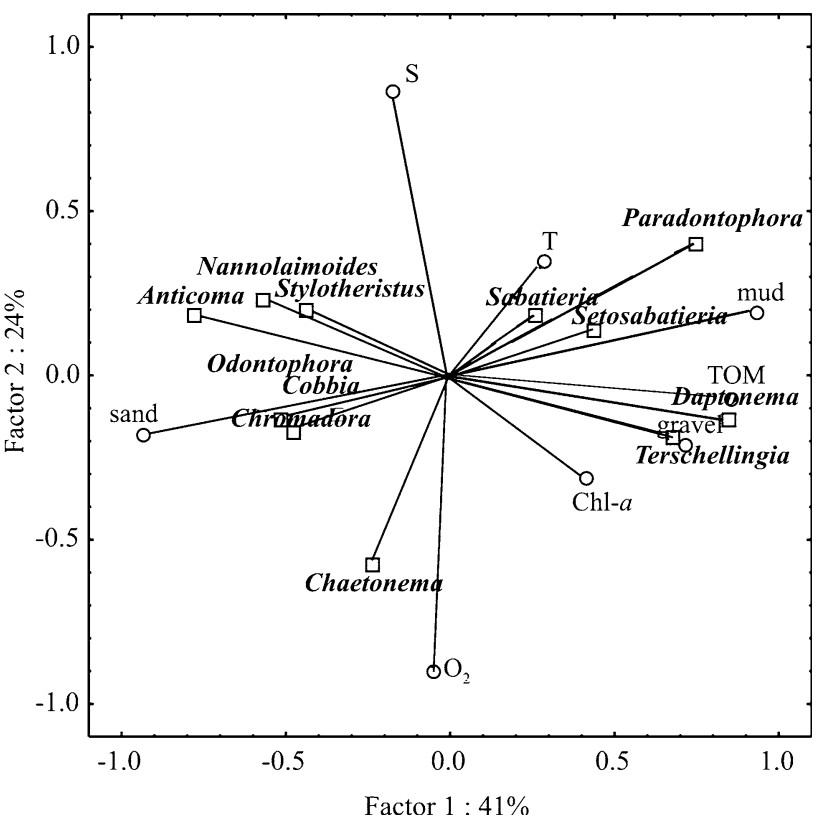

Fig. 10 PCA analysis carried out on the main environmental variables of the Foglia and Metauro rivers. The relative abundances of the more abundant nematode genera were projected on the factor plane as supplementary variables without contributing to the results of the analysis

offshore, as has also been reported by others (Albertelli et al. 1999; Occhipinti-Ambrogi et al. 2002), likely in relation to the higher mud and TOM contents. The higher organic content of fine fraction most likely determined a reduction in oxygen concentration within the sediments as a result of bacterial and chemical degradation activities. As a consequence, the characteristics of the offshore sediments could have limited the abundance of suspension-feeding 


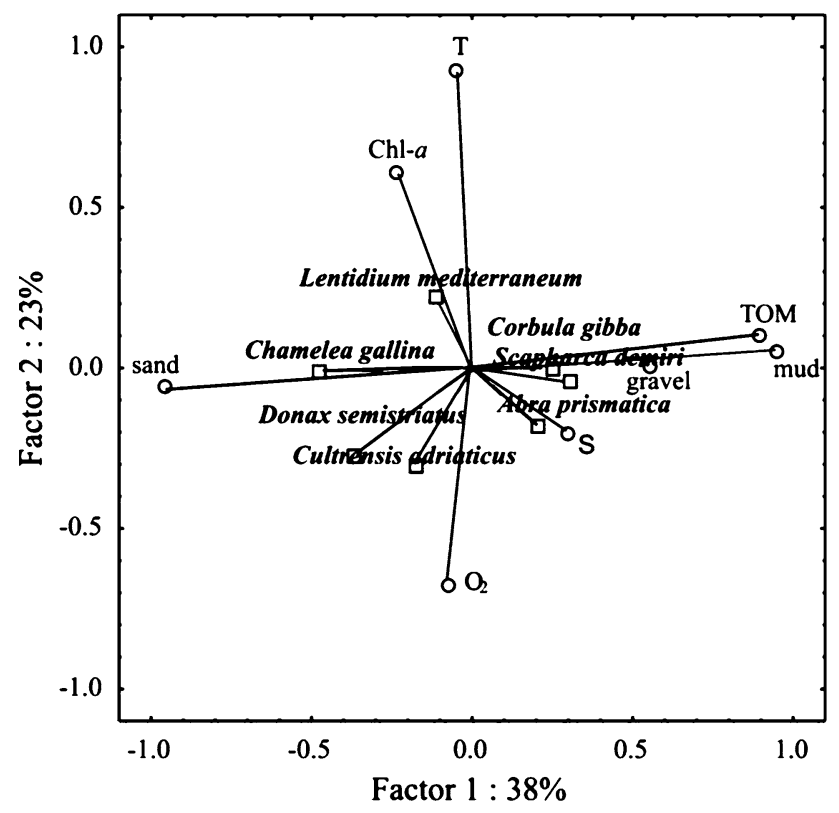

Fig. 11 PCA analysis carried out on the main environmental variables of the whole area. The relative abundances of the more abundant mollusc species were projected on the factor plane as supplementary variables without contributing to the results of the analysis

bivalves that, at the same time, favour the increase in the infaunal benthos represented by deposit feeders tolerant to oxygen reduction (e.g. annelids). The composition of the mollusc community present in the deepest stations supports this theory as it was characterised by species typical of muddy sediments, like the tolerant $A$. prismatica and the opportunistic C. gibba and S. demiri (Moodley et al. 1998;
Simboura and Zenetos 2002) (Fig. 11). C. gallina, D. semistriatus and $C$. adriaticus were more highly prominent in the sandy fraction; indeed, these species are typical of shallow and well-sorted sands and the presence of $C$. adriaticus seemed to be particularly linked to a good oxygen supply (Fig. 11).

Of the different communities studied, nematodes presented the greatest differences between the two sampling depths. In particular, the richest families (Xyalidae, Chromadoridae, Axonolaimidae and Linhomoidae) were among those also indicated by Travizi and Vidakovic (1997) as being the most diverse and abundant in the northern Adriatic Sea. Some of the most abundant families (Comesomatidae, Xyalidae and Axonolaimidae) are generally typical of muddy sediments (Heip et al. 1985), with the exception of Anticomidae, which have been found exclusively in shallow waters, confirming their ecological preference for coarser sediments (Wieser 1959).

The large differences in nematode community structures found between inshore and offshore sediments confirmed that even slight variations in sediment grain size can influence these communities (Steyaert et al. 2003). The relatively high level of habitat heterogeneity, in particular the sediment grain sizes present in the inshore stations, was probably responsible not only for a particular community composition, but also for its higher degree of diversity and evenness. This in agreement with other data within the literature, which report that diversity increases with increases in medium grain size (Heip et al. 1985; Steyaert et al. 1999; Vanaverbeke et al. 2002). Offshore, a few genera were clearly dominant and generally appeared to
Fig. 12 PCA analysis carried out on the three benthic components of the Foglia and Metauro rivers as active variables

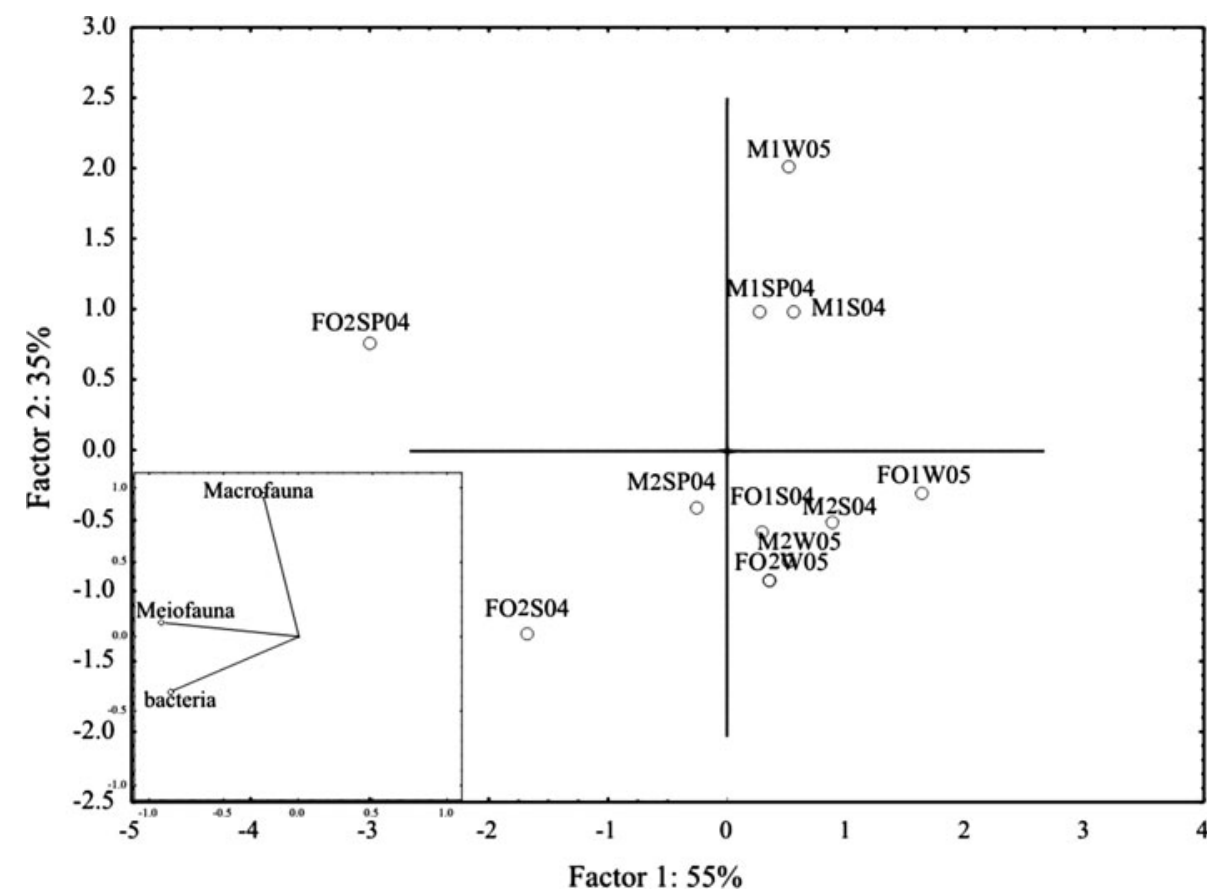


follow the TOM and mud contents (Fig. 10). The presence of a typical element of the 'thiobios', like Terschellingia longicaudata, indicates anoxic conditions (Jensen 1983), again supporting the observations of the mollusc community. To reiterate, the very high content of organic matter could have produced a strong oxygen depletion, as is supported by the presence of wide black spots in the cores obtained from the offshore samples.

The trophic groups seemed to reflect the sediment distribution and nematode ecological preferences. Epistrate feeders were most abundant at the inshore station of the river Foglia, that was characterised by well-sorted fine sands with a low content of silt and clay (Wieser 1959; Buchholz and Lampadariou 2002). In contrast, the nonselective and selective deposit feeders, which are normally common in very fine sediments (Heip et al. 1985), were the only dominant groups offshore. Surprisingly, no significant correlations were detected between bacteria and selective deposit feeder nematodes (1A). Even if Wieser's classification has been largely revisited and modified (Moens and Vincx 1997), the use of trophic groups in field research is still hampered by the limited number of nematode genera considered by Authors.

Predation of the permanent meiofauna over the juvenile macrofauna (the 'meiofaunal bottleneck hypothesis' Zobrist and Coull 1992) and competition for the food resource (Albertelli et al. 1999; Covazzi Harriague et al. 2006) are well-known with regard to soft-bottom benthic systems, but no evidence for such interactions was found in this study. The PCA results testing the interaction of the three benthic communities highlighted that most of the stations presented a similar ratio of meiofauna and macrofauna (Fig. 12) (this was even more evident when the whole area was considered, data not shown). The few exceptions seemed to confirm that meiofauna and macrofauna were not spatially distributed according to nutritional interactions or competition but instead in accordance with habitat characteristics. The abundances of bacteria and meiofauna show parallel trends thus it is unlikely that the predation of meiofauna on bacteria has a negative impact upon the bacterial abundances in this coastal study area.

Disturbance of the benthic communities by the rivers

The strong dominance of nematodes in the meiofaunal community (on average $94 \%$ of total community), as well as the low number of copepods, could be related to the generally fine grain size of the sediments, which is considered, as verified above, a 'super factor' in meiobenthic ecology (Platt et al. 1984; Heip et al. 1985). Copepod abundance was lower inshore than offshore with a trend opposite to that detected in a neighbouring area characterised by a similar distribution pattern of sediments and of organic matter (Balsamo et al. 2003). As copepods often show a preference for sediments with larger grain sizes that are rich in $\mathrm{O}_{2}$ (Murrell and Fleeger 1989) and can show a remarkable sensitivity to environmental perturbations (Hicks and Coull 1983; Van Damme et al. 1984), the lower densities inshore found in this study could represent a consequence of stress conditions in the area immediately adjacent to the shore. In the study area, concentrations of some heavy metals ( $\mathrm{Pb}, \mathrm{Ni}, \mathrm{As})$ between effect-range low (ERL) and effect-range median (ERM) criteria proposed by National Oceanic and Atmospheric Administration (NOAA) were reported for the same period by Coccioni et al. (2005); in fact they recorded higher concentrations of $\mathrm{Pb}$ in the shallow waters. The Authors also reported a total absence of the coastal community of benthic foraminifera, which seem to be highly sensitive to heavy metals (Frontalini and Coccioni 2008), as copepods are (Somerfield et al. 1994). Lee et al. (2001) have suggested that the harpacticoid copepod density may itself be a useful indicator of stress by metal pollution.

The long-shore current pattern could explain the high meiobenthic diversity and copepod abundances found off Pesaro. Although the general thermohaline currents in the western Adriatic Sea flow southward, the wind-driven long-shore current flows northward, exerting its influence along the coast (Artegiani et al. 1997; Colantoni et al. 1997). It is probably for this reason why the river Foglia did not seem to cause a disturbance in the area off Pesaro. In contrast, due to the long-shore currents, the Arzilla stream and river Metauro could have been responsible for the lower level of meiofaunal diversity and for the higher abundance of nematodes - a taxon generally considered to be very resistant to stress (Heip et al. 1985; Vincx and Heip 1987) — along the coast to Sejore. The lower salinity values detected in the area between the Metauro and Sejore during spring 2004 could be evidence of the greater effects occurring northward of these currents. Indeed, spring 2004 was characterised by abundant rains and thus a consequent increase in inputs from river runoff (indicated by the considerable reduction of salinity at coastal stations) (http://www.protezionecivile.marche.it).

The results from ANOVA highlight that the impact of the rivers especially on the meiobenthic community can vary in intensity in relation to the season and in particular with the occurrence and quantity of rain. A clear example of this was observed in spring 2004 when the increase in river runoff inputs led to a general enhancement of nematode percentages, reducing the usual differences found between the coastline and offshore over the whole area.

Concerning the nematode community, it showed diversity values comparable with those reported from other areas of the northern Adriatic Sea, with similar sediment grain size but subject to eutrophication phenomena or to waste inputs 
from rivers (Vidakovic 1988; Travizi and Vidakovic 1994). The low values of the nematode Maturity Index and especially the notable dominance of general opportunistic genera $(c-p=2)$ of nematodes suggest a high stress level in the areas adjacent to the river mouths. General opportunistic genera $(c-p=2)$ are known to increase in abundance during adverse conditions and are also indicated in the literature as being a dominant group under stress induced by heavy metals (Bongers and Bongers 1998; Gyedu-Ababio and Baird 2006). In this study, the maturity index appears to be a good indicator of the stress induced by the river input, better than the diversity indices; this is probably because it is influenced to a lesser extent by the differences in sediment granulometry. Interestingly, even if significant seasonal fluctuations were not present, during the spring of 2004, lower MI values were detected inshore compared to offshore, whilst during the summer of the same year and the winter of 2005 an opposite trend was found. This might be due to the spring riverine inputs and to the greater $\mathrm{Pb}$ concentrations that were detected inshore during the same period by Coccioni et al. (2005).

Overall, there was no evidence of the river having an impact upon the macrofauna that presented a rather homogeneous structure along the study coastline and during the study period. It was likely to be controlled to a greater extent by food supply and by the sedimentary parameters than by anthropogenic activities. Nevertheless, the low presence of amphipods at the Sejore station that could confirm a bad state of this station is worth noting.

\section{Conclusions}

In the present study, preliminary information about the benthic community composition and abundance of a coastal area of the Marches (Adriatic Sea, Italy) is reported. In particular, a record 14 genera were found for the first time in the Upper Adriatic Sea (although the identification of nematodes was only performed at the genus level); this result is important for the integration of faunistic checklists of Italian marine nematodes (Semprucci et al. 2008). The communities appeared to be significantly diverse at different depths, especially when the interaction of season was considered. One cause of this was most likely the different seasonal influences of river inputs. Sediment grain size appeared to be the main natural variable that affects the distribution and composition of these communities, influencing directly or indirectly the interstitial spaces, the oxygen levels and the food supply. Trophic resources also appeared to affect the communities: for example, TOM promoted bacterial and meiofaunal abundances and limited the macrofaunal abundances, whilst Chl- $a$ resulted as being significantly linked to the abundance of copepods and $L$. mediterraneum. Competition for food sources and predatory pressure between the three size groups cannot be excluded, even if the spatial distribution of the communities seemed to follow the habitat characteristics rather than abide to interactions between the communities.

Meiofauna appear to be the most useful community for detecting disturbances and river influences. In particular, the low copepod abundance inshore could be a good indication of stress along the area closer to the coast. Furthermore, the data on meiofauna and nematode communities suggested the presence of some disturbance sources originating not only from the main rivers (Foglia and Metauro) as expected, but also from a minor stream such as the Arzilla.

Acknowledgments This study was carried out as part of the Project CIP (Coste Italiane Protette), co-ordinated by Prof. Rodolfo Coccioni and co-financed by the Marches Region (CIPE36/02) (Italy). We are grateful to anonymous referees who gave constructive comments to improve the manuscript. We would like also to thank all the project participants and in particular Dr. Eleonora Polidori and Dr. Stefania D'Arpa for their help during the macro- and meiofaunal analyses, Dr. Daniela Mencucci and Dr. Giuseppe Baldelli for the sedimentological analysis, Dr. Manuela Ceccarini for total organic matter analysis and finally the ARPAM for its essential support during sampling.

\section{References}

Albertelli G, Covazzi-Harriague A, Danovaro R, Fabiano M, Fraschetti S (1999) Differential responses of bacteria, meiofauna and macrofauna in a shelf area (Ligurian Sea, NW Mediterranean): role of food availability. J Sea Res 42:11-26

Artegiani A, Bregant D, Paschini E, Pinardi N, Raicich F, Russo A (1997) The Adriatic Sea general circulation part II: baroclinic circulation structure. J Phys Oceanogr 27:1515-1532

Austen MC, Widdicombe S (2006) Comparison of the response of meio- and macrobenthos to disturbance and organic enrichment. J Exp Mar Biol Ecol 330:96-104

Balsamo M, Semprucci F, Mosci D (2003) La meiofauna del tratto costiero della falesia del Monte San Bartolo. In: Coccioni R (ed) Verso la gestione integrata della costa del Monte San Bartolo: risultati di un progetto pilota. Quaderni del Centro di Geobiologia, Univ Urbino, vol 1. Arti STIBU, Urbania, pp 63-75

Bell SS, Coull BC (1980) Experimental evidence for a model of juvenile macrofauna-meiofauna interactions. In: Tenore KR, Coull BC (eds) Marine benthic dynamics, vol 11. University of South Carolina Press, Columbia, pp 179-192

Bilyard GR (1987) The value of benthic infauna in marine pollution monitoring studies. Mar Pollut Bull 18:581-585

Bongers $T$ (1990) The maturity index: an ecological measure of environmental disturbance based on nematode species composition. Oecologia 83:14-19

Bongers T, Bongers M (1998) Functional diversity of nematodes. Appl Soil Ecol 10:239-251

Bongers T, Alkemade R, Yeates GW (1991) Interpretation of disturbance-induced maturity decrease in marine nematode assemblages by means of the Maturity Index. Mar Ecol Prog Ser 76:135-142

Bongers T, de Goede RGM, Korthals GW, Yeates GW (1995) An update to the cp-rating of nematode genera can be found in 
proposed changes of c-p classification for nematodes. Russ $\mathrm{J}$ Nematol 3:61-62

Boon AR, Duineveld GCA (1998) Chlorophyll $a$ as a marker for bioturbation and carbon flux in southern and central North Sea sediments. Mar Ecol Prog Ser 162:33-43

Buchanan JB, Kain JM (1971) Measurement of the physical and chemical environment. In: Holme NA, McIntyre AD (eds) Methods for the study of marine benthos. Blackwell, Oxford, pp 30-52

Buchholz TG, Lampadariou N (2002) Changes in composition and diversity of Malia bay nematode community (Crete, Greece) in relationship to sediment parameters. In: Bright $\mathrm{M}$, Dworschak PC, Stachowitsch M (eds) The Vienna school of marine biology: a tribute to Jörg Ott. Facultas Universitätsverlag, Wien, pp 33-52

Coccioni R, Frontalini F, Marsili A, Troiani F (2005) Foraminiferi bentonici e metalli in traccia: implicazioni ambientali. In: Coccioni $\mathrm{R}$ (ed) La dinamica evolutiva della fascia costiera tra le foci dei fiumi Foglia e Metauro: verso la gestione integrata di una costa di elevato pregio ambientale. Quaderni del Centro di Geobiologia, Univ Urbino, vol 3. Arti Grafiche STIBU, Urbania, pp 57-92

Colantoni P, Gabbianelli G, Mancini F, Bertoni W (1997) Coastal defence by break water and sea level rise: the case of the Italian Northern Adriatic Sea. Bull Inst Oceanogr (Monaco) 18:133-148

Covazzi Harriague A, Gaozza L, Montella A, Misic C (2006) Benthic communities on a sandy Ligurian beach (NW Mediterranean). Hydrobiologia 571:383-394

Covazzi Harriague A, Albertelli G, Bonomi A, Fabiano M, Zunini Sertorio T (2007) Pelagic-benthic coupling in a subtidal system of the North-Western Mediterranean. Chem Ecol 23:263-277

Covazzi-Harriague A, Bittoni P (2003) Struttura delle comunità macrobentoniche e contenuto di sostanza organica nell'area costiera compresa tra i fiumi Tavolo e Foglia. In: Coccioni $\mathrm{R}$ (ed) Verso la gestione integrata della costa del Monte San Bartolo: risultati di un progetto pilota. Quaderni del Centro di Geobiologia, Univ Urbino, vol 1. Arti Grafiche STIBU, Urbania, pp 77-97

Danovaro R (2000) Benthic microbial loop and meiofaunal response to oil-induced disturbance in coastal sediments: a review. Int $\mathbf{J}$ Environ Pollut 13:380-391

Danovaro R, Gambi C, Manini E, Fabiano M (2000) Meiofauna response to a dynamic river plume front. Mar Biol 137:359-370

Folk RL, Wards WC (1957) Brazos River Bar: a study in the significance of grain size parameters. J Sediment Petrol 27:3-26

Franco P, Jeftic L, Malanotte-Rizzoli P, Michelato A, Orlic M (1982) Descriptive model of the northern Adriatic. Oceanol Acta 5:379_ 389

Frontalini F, Coccioni R (2008) Benthic foraminifera for heavy metal pollution monitoring: a case study from the central Adriatic Sea coast of Italy. Estuar Coast Shelf Sci 76:404-417

Gee JM (1987) Impact of epibenthic predation on estuarine intertidal harpacticoid copepod populations. Mar Biol 96:497-510

Gyedu-Ababio TK, Baird D (2006) Response of meiofauna and nematode communities to increased levels of contaminants in a laboratory microcosm experiment. Ecotoxicol Environ Saf 63:443-450

Heip C, Vincx M, Vranken G (1985) The ecology of marine nematodes. Oceanogr Mar Biol Annu Rev 23:399-489

Herndl GJ, Peduzzi P, Fanuko N (1989) Benthic community and microbial dynamics in the Gulf of Trieste (Northern Adriatic Sea). Mar Ecol Prog Ser 53:169-178

Hicks GRF, Coull BC (1983) The ecology of marine meiobentic harpacticoid copepods. Oceanogr Mar Biol Annu Rev 21:67-175

Jensen P (1983) Meiofaunal abundance and vertical zonation in a sublittoral soft bottom, with a test of the Haps corer. Mar Biol 74:319-326
Lee MR, Correa JA, Castilla JC (2001) An assessment of the potential use of the nematode to copepod ratio in the monitoring of metals pollution. The Chañaral case. Mar Pollut Bull 42:696-701

McIntyre AD, Warwick RM (1984) Meiofauna techniques. In: Holme NA, McIntyre AD (eds) Methods for the study of marine benthos. Blackwell, Oxford, pp 217-244

Moens T, Vincx M (1997) Observations on the feeding ecology of estuarine nematodes. J Mar Biol Assoc U K 77:211-227

Møhlenberg F, Kiørboe T (1981) Growth and energetics in Spisula subtruncata (Da Costa) and the effect of suspended bottom material. Ophelia 20:79-90

Montagna PA (1984) In situ measurement of meiobenthic grazing rates on sediment bacteria and edaphic diatoms. Mar Ecol Prog Ser 18:119-130

Moodley L, Heip CHR, Middelburg JJ (1998) Benthic activity in sediments of the northwestern Adriatic Sea: sediment oxygen consumption, macro- and meiofauna dynamics. J Sea Res 40:263-280

Murrell MC, Fleeger JW (1989) Meiofauna abundance on the Gulf of Mexico continental shelf affected by hypoxia. Cont Shelf Res 9:1049-1062

Nilson P, Jönsson B, Lindström-Swanberg I, Sundbäk K (1991) Response of a marine shallow-water sediment system to an increased load of inorganic nutrients. Mar Ecol Prog Ser 71:275290

Occhipinti-Ambrogi A, Favruzzo M, Savini D (2002) Multi-annual variations of macrobenthos along the Emilia-Romagna Coast (Northern Adriatic). PSZN I Mar Ecol 23:307-319

Orlic M, Gacic M, La Violette PE (1992) The currents and circulation of the Adriatic Sea. Oceanol Acta 15:102-124

Papageorgiou N, Moreno M, Marin V, Baiardo S, Arvanitidis C, Fabiano M, Eleftheriou A (2007) Interrelationships of bacteria, meiofauna and macrofauna in a Mediterranean sedimentary beach (Maremma Park, NW Italy). Helgol Mar Res 61:31-42

Platt HM, Warwick RM (1983) Free-living marine nematodes. Part I. British enoplids. Synopses of the British Fauna (New Series), vol 28. Cambridge University Press, Cambridge, 307 pp

Platt HM, Warwick RM (1988) Free-living marine nematodes. Part II. British chromadorids. Synopses of the British Fauna (New Series), vol 38. Brill, Leiden, $502 \mathrm{pp}$

Platt HM, Shaw KM, Lambshead PJD (1984) Nematode species abundance patterns and their use in the detection of environmental perturbations. Hydrobiologia 118:59-66

Reise K (1985) Tidal flat ecology. An Experimental approach to species interactions. In: Ecological studies, vol 54. Springer, Berlin, $191 \mathrm{pp}$

Schwinghamer $\mathrm{P}$ (1988) Influence of pollution along a natural gradient and in a mesocosm experiment on biomass-size spectra of benthic communities. In: Bayne BL, Clarke KR, Gray JS (eds) Biological effects of pollutants. Results of a practical workshop. Mar Ecol Prog Ser 46:199-206

Semprucci F, Sandulli R, De Zio-Grimaldi S (2008) Adenophorea nematode marini. In: Relini G (ed) Checklist della flora e della fauna dei mari italiani. Biol Mar Mediterr 15 (suppl):184-209

Simboura N, Zenetos A (2002) Benthic indicators to use in Ecological Quality classification of Mediterranean soft bottom marine ecosystems, including a new Biotic Index. Medit Mar Sci Vol 3(2):77-111

Somerfield PJ, Gee JM, Warwick RM (1994) Soft sediment meiofaunal community structure in relation to a long-term heavy metal gradient in the Fal estuary system. Mar Ecol Prog Ser 105:79-88

Steyaert M, Garner N, Gansbeke D, Vincx M (1999) Nematode communities from the North Sea: environmental controls on species diversity and vertical distribution within the sediment. J Mar Biol Assoc U K 79:253-264 
Steyaert M, Vanaverbeke J, Vanreusel A, Barranguet C, Lucas C, Vincx M (2003) The importance of fine-scale, vertical profiles in characterising nematode community structure. Estuar Coast Shelf Sci 58:353-366

Tenore KR, Rice DL (1980) A review of trophic factors affecting secondary production of deposit-feeders. In: Tenore KR, Coull BC (eds) Marine benthic dynamics, vol 11. University of South Carolina Press, Columbia, South Carolina, USA, pp 325-340

Tita G, Desrosiers G, Vincx M, Nozais C (2000) Predation and sediment disturbance effects of the intertidal polychaete Nereis virens (Sars) on associated meiofaunal assemblages. J Exp Mar Biol Ecol 243:261-282

Travizi A, Vidakovic J (1994) An evaluation of eutrophication effects on northern Adriatic meio- and nematofauna communities. Period biol 96:469-473

Travizi A, Vidakovic J (1997) Nematofauna in the Adriatic Sea: review and check-list of free-living nematode species. Helgol Meeresunters 51:503-519

Van Damme D, Heip C, Willems KA (1984) Influence of pollution on the harpacticoid copepods of two North Sea estuaries. Hydrobiologia 112:143-160

Van Duyl FC, Kop AJ (1994) Bacterial production in North Sea sediments: clues to seasonal and spatial variations. Mar Biol 120:323-337

Vanaverbeke J, Gheskiere T, Steyaert M, Vincx M (2002) Nematode assemblages from subtidal sandbanks in the southern bight of the north sea: effect of small sedimentological differences. J Sea Res 48:197-207
Veggiani A (1965) Trasporto di materiale ghiaioso per correnti di riva dall'area marchigiana all'area Emiliana durante il Quaternario. Boll Soc Geol It 34:1-16

Vidakovic J (1988) Meio- and nematofauna from Rasa bay (North Adriatic sea, Yugoslavia). Vie Milieu 38:213-220

Vincx M, Heip C (1987) The use of meiobenthos in pollution monitoring studies: a review. ICES, C.M. E33L (1166):1-18

Warwick RM, Platt HM, Somerfield PJ (1998) Free-living marine nematodes. Part III. British monhysterids. Synopses of the British Fauna (New Series), vol 53. Field Studies Council, Shrewsbury, UK, 296 pp

Wieser W (1953) Die Beziehung zwischen Mundhöhlengestalt, Ernährungsweise und Vorkommen bei freilebenden marinen nematoden. Eine okologisch-morphologische studie. Ark Zool 4:439-484

Wieser W (1959) Free-living marine nematodes. IV. General part. Reports of the Lund University Chile expedition 1948-1949. Univ Lund N F 55:1-111

Zavatarelli M, Baretta JW, Baretta-Bekker JG, Pinardi N (2000) The dynamics of the Adriatic Sea ecosystem. An idealized model study. Deep Sea Res I 47:937-970

Zobrist EC, Coull BC (1992) Meiobenthic interactions with macrobenthic larvae and juveniles: an experimental assessment of the meiofaunal bottleneck. Mar Ecol Prog Ser 88:1-8. http://www. protezionecivile.marche.it 